\title{
A PROPOSED HYPOGENIC ORIGIN OF IRON ORE DEPOSITS IN SOUTHEAST MINNESOTA KARST
}

\author{
E. Calvin Alexander, Jr.
}

Earth Sciences Dept., University of Minnesota, 310 Pillsbury Dr. SE, Minneapolis, MN 55455, USA, alexa001@umn.edu

Betty J. Wheeler

Earth Sciences Dept., University of Minnesota, 310 Pillsbury Dr. SE, Minneapolis, MN 55455, USA, whee0023@umn.edu

\begin{abstract}
From 1942 through 1968 there was an active iron ore mining industry in western Fillmore, eastern Mower and southern Olmsted Counties of Minnesota. This iron mining district was 250 miles south of, and the ores were a billion years younger than, the ores of the classic iron mining districts in northern Minnesota. The high grade iron ore was mostly goethite and hematite and occurred as near-surface relatively small pods which unconformably filled paleokarst depressions in the Devonian Spillville Formation and the Ordovician Stewartville Formation.
\end{abstract}

The source of the iron has long been cryptic. The available field and textural evidence is consistent with a hypogenic origin of these iron deposits. Before the current Mississippi River drainage system was incised, regional ground water flow systems could have emerged through the karst conduits in the Paleozoic carbonates. The waters in the deeply buried aquifers underlying this area currently are anoxic and enriched in dissolved ferrous iron and would have been more so before the entrenchment of the Mississippi River reorganized the regional ground water flow system. When that water emerged into the atmosphere the ferrous iron would have quickly been oxidized by a combination of biotic and abiotic processes producing the ferric oxide ore at the spring orifices. Numerous springs and seeps in Minnesota are currently building iron oxide deposits at their orifices.

\section{Introduction}

The presence of iron ore deposits in southern Minnesota has been recognized since Winchell and Upham's (1884) report. These deposits occur on top of Paleozoic sedimentary rocks and are often covered by Pleistocene glacial deposits. They are distinctly separated in time and space from the major Precambrian iron ore deposits in northern Minnesota (Morey, 1998). The high grade iron ore was mostly goethite and hematite and occurred as near-surface, relatively small pods which unconformably filled paleokarst depressions in the Devonian Spillville Formation and the Ordovician Stewartville Formation. "Following extensive exploration work that was conducted in the 1930s, two companies carried out mining operations in the Fillmore County district from 1942 to 1968 . Cumulative production was 8.1 million tons of iron ore" (Bleifuss, 1972 p.498).

The deposits were often adjacent to or cementing discontinuous bodies of the nominally Cretaceous Ostrander Gravels. The ore bodies were covered with a few meters of unconsolidated Pleistocene glacial drift and loess and Holocene sediments. The mining was accomplished with bulldozers, front end loaders and dump trucks. The ore was shipped by rail mainly to mills in the St. Louis area.

The iron ores are conventionally mapped as the Iron Hill Member of the Windrow Formation (Andrews, 1958). Andrews' (1958) stratigraphic study of the Windrow Formation in the Upper Mississippi Valley, mainly southern Minnesota, southwestern Wisconsin and in northern Iowa, reviewed the literature up to 1958. Based on the literature and his own extensive work, Andrews (1958, p. 597) concluded "It seems probable that the Iron Hill member was deposited as a result of reaction of iron-charged waters with carbonate bedrock."

Rodney Bleifuss' PhD thesis (Bleifuss, 1966) and subsequent publication (Bleifuss, 1972) are the most definitive works on the origin of the iron ores of southeastern Minnesota. Bleifuss' thesis work was conducted during the active phase of the iron mining. He observed, studied, and documented many of the iron ore 
bodies as they were being mined. Bleifuss (1972, p. 498) summarized the previous conceptual model as:

1. "The ores were formed by weathering of the underlying limestone units;

2. The development of the ore bodies required some supplementary process of concentration, involving migration and local concentration of iron during the weathering cycle;

3. The age of the Windrow Formation is Cretaceous, and the deposits in the Fillmore County district are correlative with similar lithologic units of known Cretaceous age in other parts of the region;

4. Fossil evidence that would positively date the Windrow Formation is absent in the district; and

5. The most likely age of the iron-rich residuum and associated iron ores is Cretaceous."

Bleifuss (1972, p. 498) argued to the contrary that his observations and data indicated "the ores are Tertiary in age, and that they were developed from the oxidation of a primary marine siderite faces of the Cedar Valley Formation."

The origin of the southeastern Minnesota iron deposits has long been cryptic and controversial and remains so. The fundamental issue, on which there is no consensus answer or model, can be summarized in simple questions. What was the source of the iron? How did that iron accumulate into mineable ore bodies in the Fillmore County district?

The thesis of this paper is that available field and textural evidence is consistent with a hypogenic origin of these iron deposits. Before the current Mississippi River drainage system developed, regional ground water flow systems could have emerged through the karst conduits in the Paleozoic carbonates. The waters in the deeply buried aquifers underlying this area currently are anoxic and enriched in dissolved ferrous iron and would have been more so before the entrenchment of the Mississippi River reorganized the regional ground water flow system. When that water emerged into the atmosphere the ferrous iron would have quickly been oxidized by a combination of biotic and abiotic processes producing the ferric oxide ores at the spring orifices.

\section{The Ore Bodies}

Location

Figure 1 shows the locations of the iron ore leases (MDM, 1941-1970) plotted on top of the bedrock geology of the mining district in western Fillmore (Mossler, 1995), eastern Mower (Mossler, 1998) and southern Olmsted (Olson, 1988) Counties in Minnesota. Figure 1 is an updating of Figure VI-43 in Bleifuss (1972, p. 499). Figure 1 is different from Bleifuss' Figure VI-43 only in the bedrock geology, which has been significantly updated. All of the ore bodies were located on what is now interpreted as either the Devonian Spillville Formation or the Ordovician Stewartville Formation. The Spillville is a subdivision of Bleifuss' (1972) Cedar Valley Formation. The Stewartville Formation is a subdivision of Bleifuss' (1972) Galena Formation.

Based on the more recent geologic mapping shown in Figure 1, for the rest of this paper we will update the formation names from Bleifuss (1966, 1972) by substituting "Spillville" for "Cedar Valley" and "Stewartville" for "Galena".

The Stewartville and Spillville Formations have the greatest secondary karst transmissivity of the geologic units shown on this map. All of the geologic units on Figure 1 regionally dip at a few feet per mile to the southwest. The iron ores are conspicuously not present on the Maquoketa and Dubuque Formations which are stratigraphically between the Stewartville and Spillville Formations.

Figure 2 is modified from Andrews' (1958) Figure 2 with the names of the geologic units updated to current nomenclature. Although Andrews did not use the word "karst", he recognized that "solution activity" was an important part of the process. Andrews (1958, p. 614-615 ) reasoned, based on the work of Krumbein and Garrels (1952), "that the iron was transported in an acidic solution ( $\mathrm{pH}$ less than 7) in the ferrous state and that deposition resulted from an increase in $\mathrm{pH}$ of the solution. This increase in $\mathrm{pH}$ may be logically attributed to the reaction of the acidic solution with carbonate bedrock and resulted in precipitation of ferric oxide from this neutralized solution. It is thought that the ferric oxide could be precipitated in this manner both at the surface and by downward-percolating waters (emphasis added) in fissures of the underlying carbonate bedrock." 


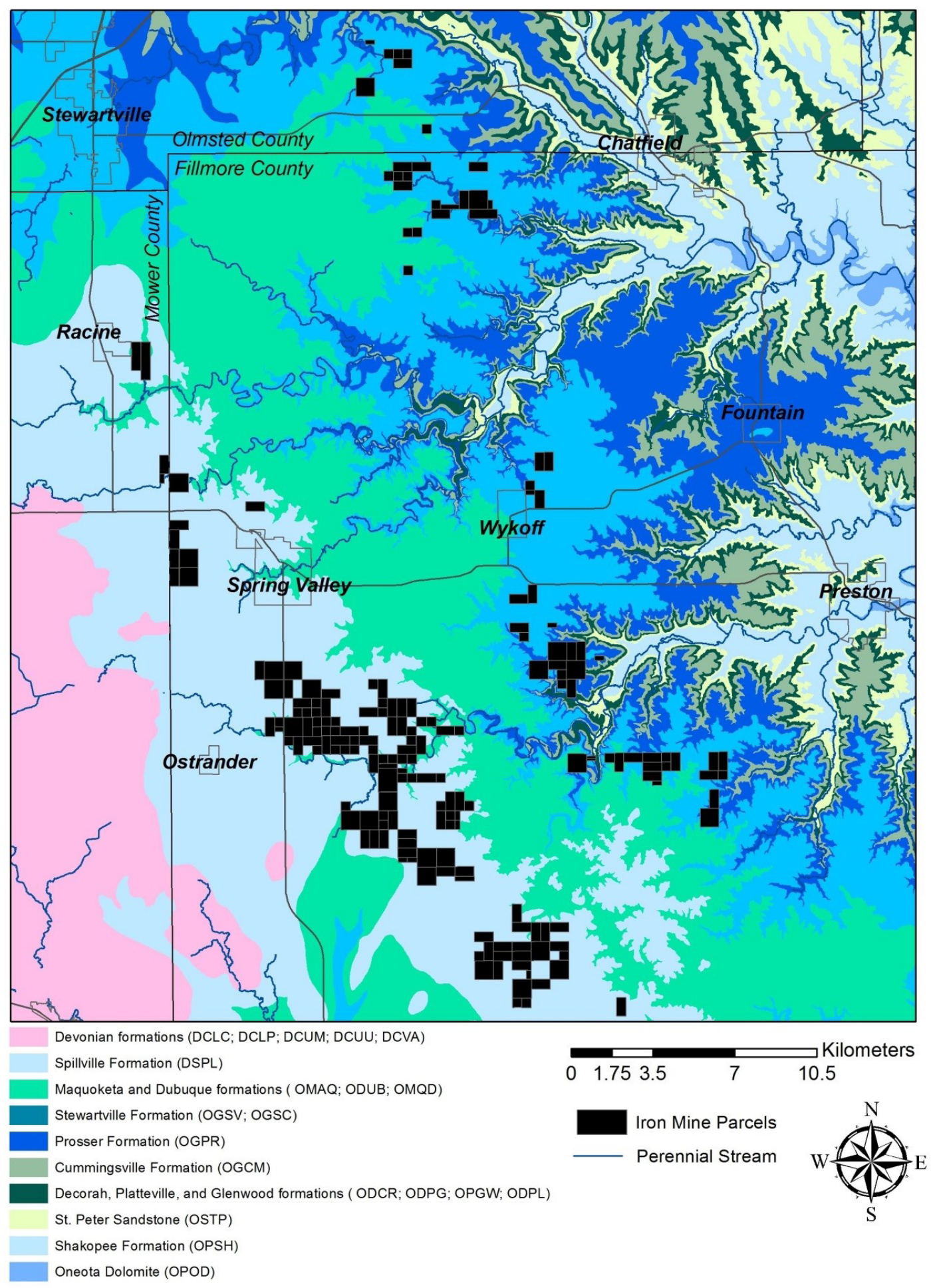

Figure 1. Iron mine parcels of the SE Minnesota iron mining district superimposed on the bedrock geology. Modified from Figure VI-43 in Bleifuss (1972). 


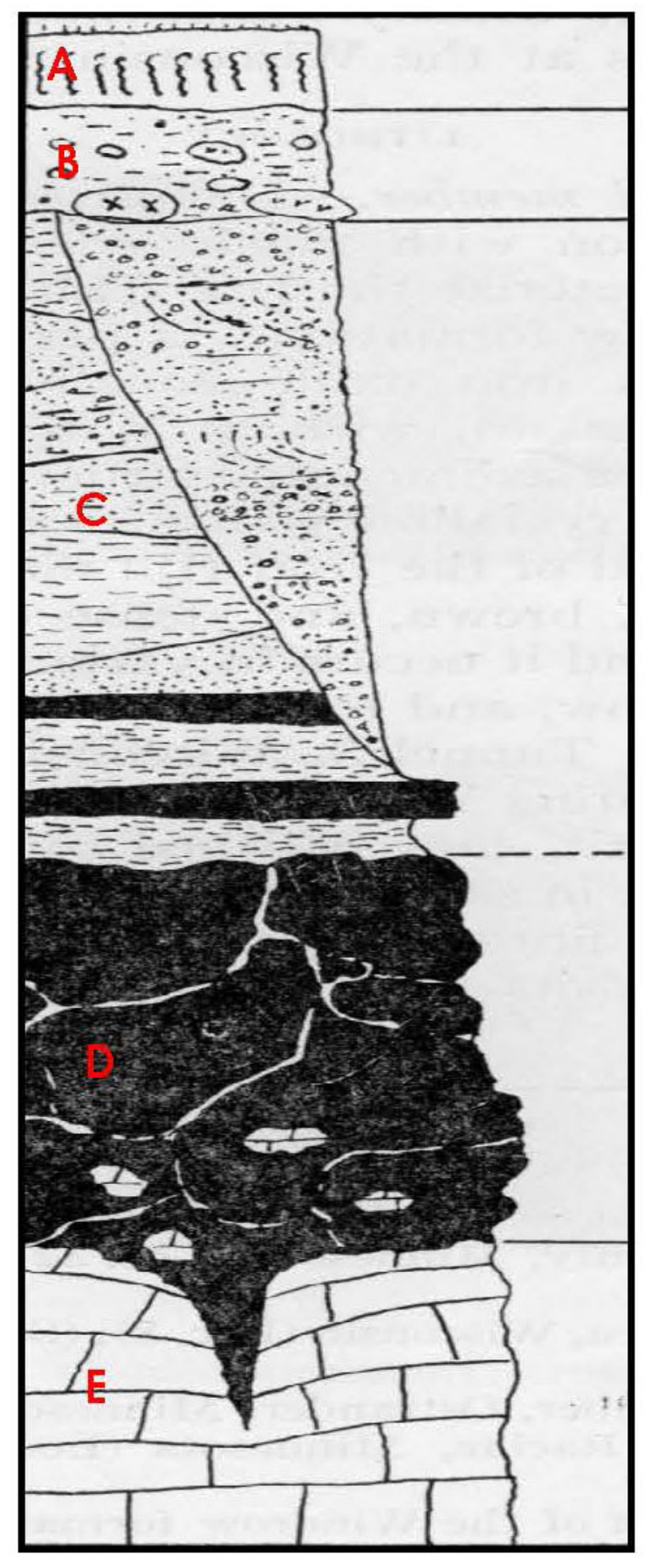

Figure 2. "Composite stratigraphic section of the Windrow formation as exposed in Fillmore County" from Andrews (1958). A = Loess, $B=$ Glacial Drift, $C=$ East Bluff Member (Ostrander Gravels), D = Iron Hill Member (15' massive, concretionary limonite, containing relics of weathered Cedar Valley Limestone (Spillville Formation), $E=$ Cedar Valley Limestone (Spillville Formation) - Badly weathered buff limestone, with slump structures produced by solution activity.

\section{Description of the Ore Bodies}

Figure 3 is a part of Plate 5 from Bleifuss (1966) showing a plan view of a cluster of ore bodies in sinkholes on the Stewartville Formation. Figure 4 is Plate 6 from Bleifuss (1966) showing three cross sections through one of the ore bodies.

The following descriptions of ore bodies are repeated here because the original exposures no longer exist.

"The ore bodies overlie either the Spillville or the Stewartville Formations, and range in thickness from 3 to 30 feet. An under clay which ranges in thickness from a few tenths of an inch to more than two feet is developed between the ore and the underlying carbonate rocks. The ore is locally overlain by decomposed Spillville Formation, residual clays, or sediments of the Ostrander Member of the Windrow Formation. Both the Spillville Formation and the Stewartville Formation beneath the ore generally are fresh, although they may have been changed to a sandy dolomite ranging in thickness from a fraction of an inch to several feet....

Although the ore bodies developed on the Spillville and Stewartville Formations are chemically and physically similar, they differ in size and shape. The ore bodies on the Spillville Formation generally have a greater areal extent, are more uniform in thickness, and have less relief than those on the Galena Formation.... Deposits containing more than 50,000 tons of ore were common.

In contrast, the ore bodies on the Stewartville Formation are isolated and generally contain much smaller tonnages. Generally, the upper surface of the ore is quite smooth, has a few closed depressions, and a relief rarely exceeding 10 feet. On a large scale, it is somewhat convex beneath the overlying unconsolidated materials....

The relief on the carbonate bedrock surface beneath the ore on the Spillville Formation is small,... In contrast, the relief beneath the ore on the Stewartville Formation is much greater, and most of the mines show prominent bedrock 'horses,' some of which are more than 30 feet high.” (Bleifuss, 1972, p. 501.) 


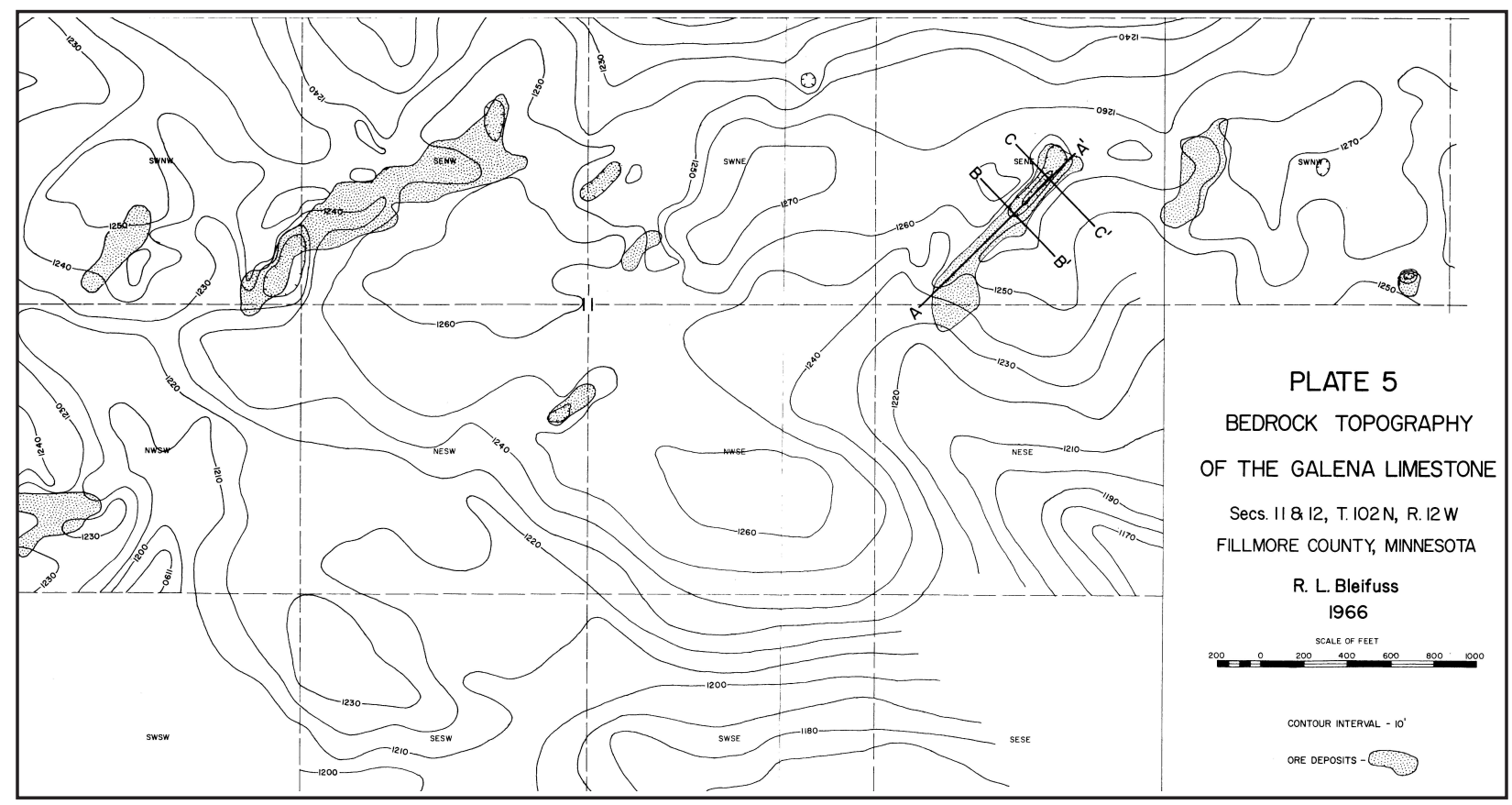

Figure 3. Plate 5 (cropped) from Bleifuss (1966). Plan view of iron ore bodies on the Stewartville Formation.

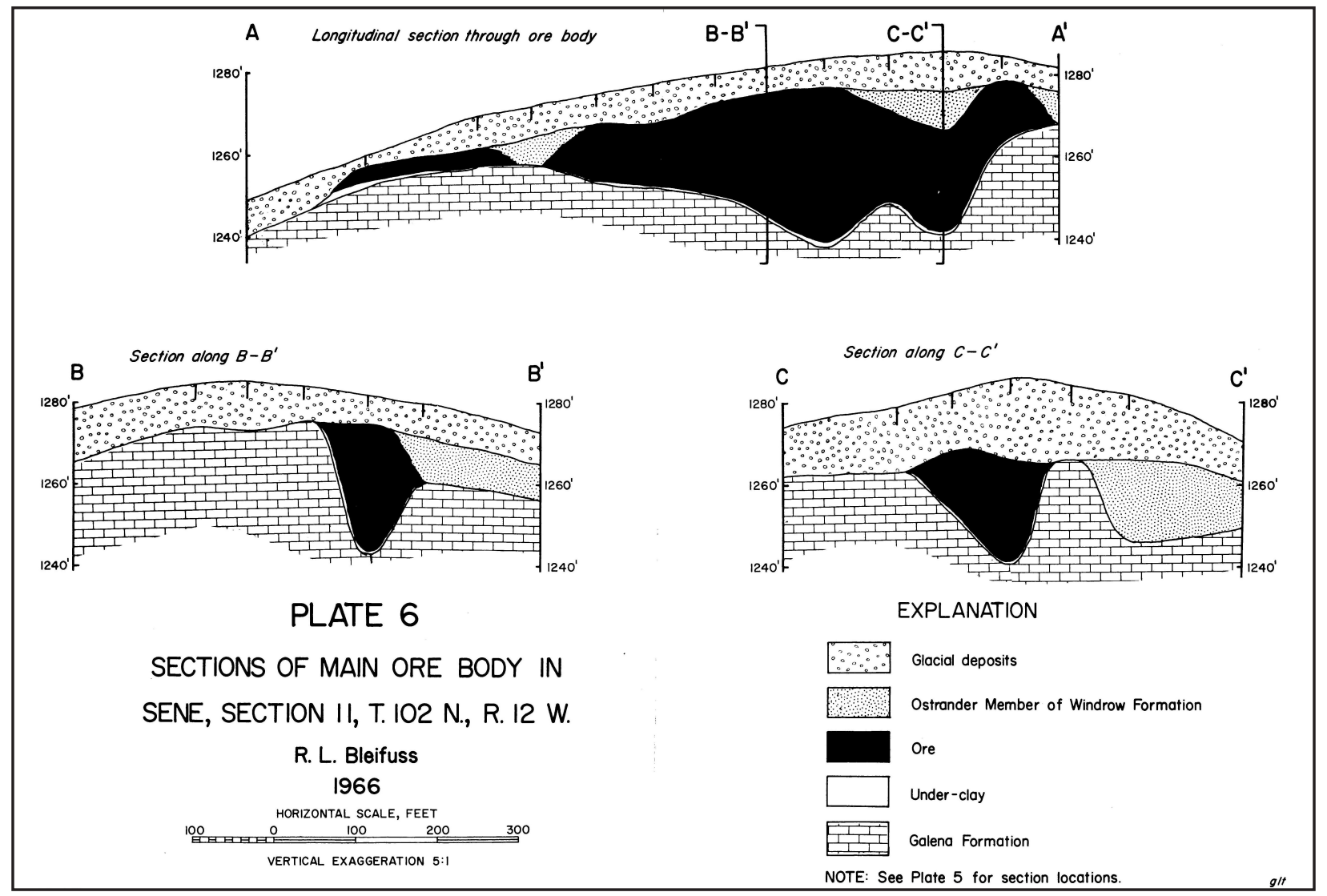

Figure 4. Plate 6 from Bleifuss (1966), cross sections of iron ore body shown in Figure 3. 


\section{Description of the Iron Ores}

"The ore is composed predominantly of the mineral goethite and has minor amounts of hematite. The major gangue constituents are silt-size quartz and minor amounts of illitic clay. Two types of ore are readily identifiable in the field - 'hard ore' and 'soft ore.' The term 'hard ore' is applied to that material in which the principal ore mineral is dense, hard, crystalline goethite. Its most striking physical characteristic in place is its coarse, broken rubbly appearance. In typical exposures, it is composed of a mass of broken, closely-packed, angular fragments, one half to two inches across, that are intermixed with nodular masses of goethite as much as 10 inches in maximum dimension. A distinct horizontal layering is visible in some exposures, with individual beds being as much as six inches thick...." (Bleifuss, 1972, p. 499-500).

\begin{abstract}
"The soft ore, in contrast, appears rather massive and structureless in the field, and lacks the rubbly or nodular structure characteristic of the hard ore. In hand specimen, it has a soft punky texture and can be carved easily with a knife. The ore has a high porosity and a low bulk specific gravity. The principal ore mineral is goethite that shows a wide range of color from the bright yellow of ocherous goethite through shades of tan, brown and dark brown, to the brilliant crimson of ocherous hematite.... the dark brown ore varieties have much more manganese (about 2.0 percent) than the yellow varieties (about 0.5 percent)." (Bleifuss, 1972, p. 499-500).
\end{abstract}

Figure 5 and Figure 6 are black and white images of samples of the hard iron ore. Figure 5 is from Stauffer and Theil (1944, Fig. 6) and Figure 6 is from Andrews (1958, Plate 1A). Both images show the layers of iron ore deposited concentrically around fragments of the limestone bedrock. Both samples are consistent with what would be expected when the iron oxides had been deposited from fluids, which flowed around and reacted with the limestone bedrock.

\section{Summary of Relevant Literature Observations}

1. Early work on the Fillmore District iron ore deposits viewed the ores as straight forward weathering residues from the underlying country rocks.
2. Andrews (1958, p. 597) argues that the iron ores were "deposited as a result of reaction of [acidic] iron-charged waters with carbonate bedrock" but doesn't suggest a source of the acidic, iron rich waters.

3. Sloan (1964, p.18) considered the iron ores and associated Ostrander Gravels of Fillmore County to be Cretaceous in age. He observed that the

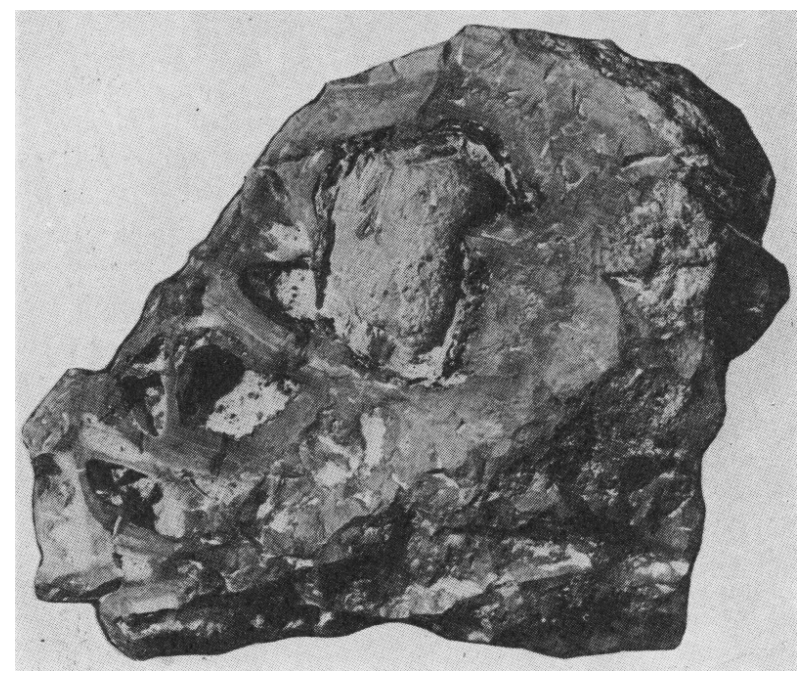

Figure 5. Hard ore deposited around and reacting with carbonate inclusions. The sample is about $10 \mathrm{~cm}$ across. (from Stauffer and Theil, 1944, Figure 6).

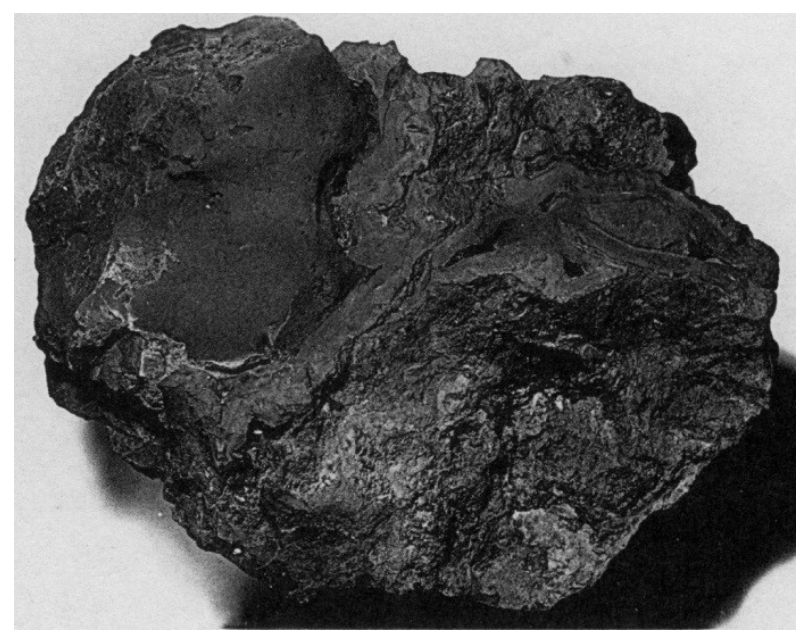

Figure 6. "Limonite of the Iron Hill member concentrically surrounding fragments of highly altered Cedar Valley Limestone [Spillville Formation], Spring Valley mine of the Hanna Company, Fillmore County, Minnesota" (from Andrews 1958, Plate 1A). The sample is about $18 \mathrm{~cm}$ across. 
iron ores "typically occur on a karst topography, primarily as fillings in enlarged joints and sinkholes or caves."

4. Bleifuss (1972, p. 498) argues that the ores were developed from the oxidation of a "primary marine siderite faces of the Cedar Valley [Spillville] Formation" but doesn't explain the textural evidence that the deposition involved flowing water.

5. The ore deposits are developed only on the Stewartville and Spillville Formations and not on the Maquoketa and Dubuque Formations.

6. The iron ores are in and associated with karst sinkholes and solutionally enlarged fractures and caves.

7. Mystery Cave, the largest cave in Minnesota, is developed in the Stewartville and Dubuque Formations, contains evidence of hypogenic speleogenesis (Klimchouk, 2007) and is overlain by one of the iron ore mines.

\section{A Hypogenic Source of the Iron Ores}

In other papers at this conference and in this paper, we are proposing that hypogenic regional groundwater flow systems have operated, and continue to operate, in southeastern Minnesota's bedrock aquifer systems. The current surface and groundwater flow systems drain to the Mississippi River and its tributaries. Older regional groundwater and surface water drainage patterns, before the current Mississippi River drainage developed, were from east to west and potentially may have been much longer.

Deep wells in southeastern Minnesota often produce waters that are very anoxic, enriched in dissolved ferrous iron, with near neutral $\mathrm{pHs}$. Some of the deep wells produce brackish to saline waters which are anoxic and iron rich.

The Stewartville and Spillville Formations in Minnesota have high secondary porosity and permeability and are regional aquifer systems. The Decorah Shale aquitard constrains the bottom of the aquifers. The Pinicon Ridge Formation aquitard constrains the top. The Maquoketa and Dubuque Formations act as aquitards to separate the two regional aquifer systems. The Stewartville and Spillville Formations are the natural discharge points, where they reach the surface, for regional groundwater flow systems.
To our knowledge none of the numerous springs issuing from the Spillville and Stewartville Formations in the iron ore district of western Fillmore County are currently depositing iron oxides. However, about $45 \mathrm{~km}$ west, in western Mower County near Austin, Minnesota, the Cedar River has eroded the thick glacial sediments of central Mower County. The first bedrock there is the Spillville Formation. There are springs in those areas which are currently depositing iron oxides (Green and others, 2002).

The sandstone karst of north-central Minnesota (Shade, 2002, Shade and others, 2015) has many springs and seeps that are currently depositing significant amounts of iron oxyhydroxides.

Figure 7 is a recent photograph of one such spring. This spring issues from an enlarged joint in the Hinckley Sandstone. When sampled on June 14, 2001, (Shade, 2002) the water was a low TDS, Ca (16.5 ppm), Fe (11.6 ppm), Mg (6.5 ppm), Na (2.3 ppm)/bicarbonate (alkalinity $=74$ as ppm $\left.\mathrm{CaCO}_{3}\right)$ water. The $\mathrm{SO}_{4}(0.52$

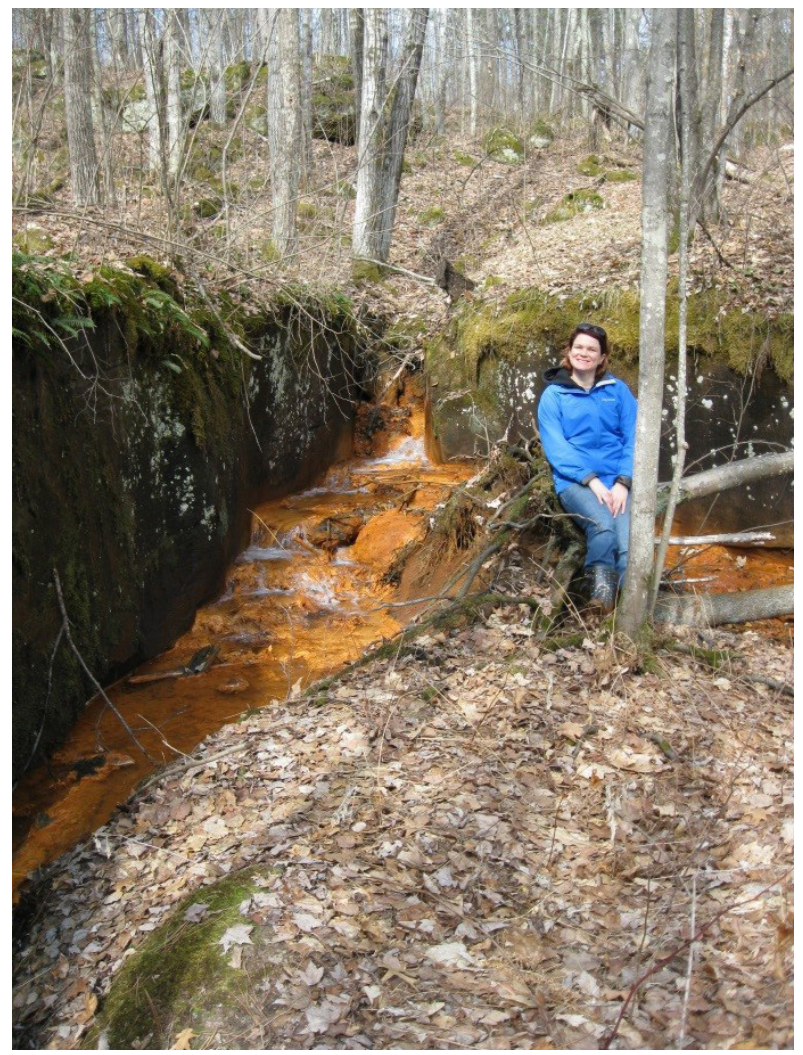

Figure 7. Gushing Orange Spring, (MN58:A00002), south of Sandstone, Pine County, Minnesota. 
ppm) and $\mathrm{Cl}(0.43 \mathrm{ppm})$ were very low. The $\mathrm{pH}$ of the water was 6.3. The leaf-covered mound in front of the lady is brown iron oxide that is several feet thick. This area was glacially scoured at the end of the Wisconsinan. The entire accumulation of material therefore must be less than about 10,000 years old.

When the anoxic, ferrous iron-enriched groundwaters discharge to the surface, both abiotic and biological processes rapidly oxidize the soluble ferrous iron to insoluble ferric iron and precipitate iron oxyhydroxides.

The oxidation of ferrous to ferric iron releases hydrogen ions which rapidly lower the $\mathrm{pH}$ and acidify the waters near the surface and at the surface.

The acidic waters aggressively react with and dissolve the carbonate bedrock at and near the surface. This enlarges the near surface fractures and creates the karst depressions that fill with the iron ore bodies. The karst depressions are enlarging as they fill with iron ore so the ores collapse on a local scale and produce the ore breccias seen in the mines.

If and when a particular hypogenic flow path becomes clogged with iron oxides, the flow will find other nearby paths to the surface and create new iron ore accumulations. Depending on the local geometry, these accumulations of iron oxides can build mounds and/or coalesce to form larger structures. The insoluble iron oxides will then tend to armor the carbonates they cover against dissolution by surface precipitation and localized topography reversals can occur.

The age of the Fillmore County iron deposits is very poorly constrained. The ores are pre-Pleistocene and are underlain by Devonian and Ordovician carbonates. Sloan (1964) concluded that the ores were Cretaceous. Bleifuss $(1966,1972)$ argued the ores are Cenozoic aged. In either case, there are $10 \mathrm{~s}$ of millions, if not a 100 million years available for their formation. Nor is there any necessity that the iron ores all formed at the same. Iron depositing springs would likely migrate across the landscape, as surface erosion and regional groundwater flow systems evolve.

Estimating the flow of the Gushing Orange Spring shown in Figure 9 at 500 liters/minute and using Shades' (2002) chemistry, we calculate that this spring discharges about 3 metric tons of iron per year. The entire Fillmore County iron ore district could easily have been produced in the available time by similar springs.

\section{Acknowledgments}

We gratefully acknowledge the positive and constructive reviews that have significantly improved this paper. The Legislative-Citizen Commission on Minnesota Resources and its predecessor, the Legislative Commission on Minnesota Resources, has supported research on southeast Minnesota karst hydrogeology since the 1980s. John Barry's GIS skills produced Figure 1.

\section{References}

Andrews GW. 1958. Windrow Formation of upper Mississippi Valley region a sedimentary and stratigraphic study. The Journal of Geology 66 (6): 597-624.

Bleifuss RL. 1966. The Origin of the Iron Ores of Southeastern Minnesota [ $\mathrm{PhD}$ thesis]. Minneapolis (MN): University of Minnesota. $125 \mathrm{p}$.

Bleifuss RL. 1972. The iron ores of southeastern Minnesota. In: Sims PK, Morey GB editors. Geology of Minnesota: a centennial volume. St. Paul (MN): Minnesota Geological Survey. p. 498505.

Green JA, Alexander EC Jr, Markin WJ, Alexander SC. 2002. Plate 10- Karst Hydrogeomorphic Units. Geologic Atlas of Mower County, Minnesota, County Atlas Series C-11. St. Paul (MN): Minnesota Department of Natural Resources.

Klimchouk AB. 2007. Hypogene speleogenesis: hydrogeological and morphogenetic perspective. Special Paper No. 1 National Cave \& Karst Research Institute, Carlsbad (NM). 106 p.

Krumbein WC, Garrels RM. 1952, Origin and classification of chemical sediments in terms of $\mathrm{pH}$ and oxidation-reduction potentials. The Journal of Geology 60 (1): 1-33.

MDM. 1941-1970. Mining directory of Minnesota series. Minneapolis (MN): University of Minnesota Mines Experiment Station. 30 volumes.

Morey GB. 1998. Mineral development in Minnesota: past history, present trends, and future possibilities. Report of Investigations 52. St. Paul $(\mathrm{MN})$ : Minnesota Geological Survey. $21 \mathrm{p}$.

Morey GB, Balaban N, Swanson L, editors. 1981. Bibliography of Minnesota geology: 1951-1980. Bulletin 46. St. Paul (MN): Minnesota Geological Survey. $143 \mathrm{p}$. 
Mossler JH. 1995. Plate 2- Bedrock Geology.

Geologic Atlas of Fillmore County, Minnesota, County Atlas Series C-8, Part A. St. Paul (MN): Minnesota Geologic Survey.

Mossler JH. 1998. Plate 2- Bedrock Geology. Geologic Atlas of Mower County, Minnesota, County Atlas Series C-11, Part A. St. Paul (MN): Minnesota Geologic Survey.

Olsen B. 1988. Plate 2-Bedrock Geology. Geologic Atlas of Olmsted County, Minnesota, County Atlas Series C-3. St. Paul (MN): Minnesota Geologic Survey.

Shade BL. 2002. The Genesis and Hydrogeology of a Sandstone Karst in Pine County, Minnesota [master's thesis]. Minneapolis (MN): University of Minnesota, $171 \mathrm{p}$.

Shade BL, Alexander EC Jr., Alexander SC. 2015. The Sandstone Karst of Pine County, Minnesota. These Proceedings. $10 \mathrm{p}$.

Sloan RE. 1964. The Cretaceous System in Minnesota. Report of Investigations 5. Minneapolis (MN): Minnesota Geologic Survey, University of Minnesota. $64 \mathrm{p}$.

Stauffer CR, Thiel GA. 1944. The iron ores of southeastern Minnesota. Economic Geology 39 (5): 327-339.

Winchell NH, Upham W. 1884. Geological and natural history survey final report 1872-1882. Volume 1. Minneapolis (MN): Minnesota Geological and Natural History Survey. 697 p. 
